Vol. 9 (2000): 23-35.

\title{
Preparation, properties and applications of wheat gluten edible films
}

\author{
Patricia Tanada-Palmu \\ Department of Food Technology, PO Box 27, FIN-00014 University of Helsinki, Finland. Current address: \\ Department of Nutrition and Food Planning, PO Box 6121, University of Campinas, Cidade Universitária Zeferino \\ Vaz, 13083-970 Campinas-SP, Brazil \\ Harry Helén and Lea Hyvönen \\ Department of Food Technology, PO Box 27, FIN-00014 University of Helsinki, Finland, \\ e-mail:lea.hyvonen@helsinki.fi
}

\begin{abstract}
Edible films from wheat gluten were prepared with various amounts of glycerol as a plasticizer. Water vapor permeability, oxygen permeability, tensile strength and percentage elongation at break at different water activities $\left(a_{w}\right)$ were measured. Films with low amounts of glycerol had lower water vapor and oxygen permeabilities, higher tensile strength and lower elongation at break. Wheat gluten coatings reduced weight loss during two weeks of storage for cherry tomatoes and sharon fruits compared to uncoated controls. A bilayer film of wheat gluten and beeswax significantly lowered weight loss from coated cheese cubes compared to single layer coating of wheat gluten.
\end{abstract}

Key words: edible film, edible coatings, tensile strength, water vapor permeability, wheat gluten

\section{Introduction}

There has been considerable recent interest in edible films for foods (Kester and Fennema 1986, Guilbert 1986, Guilbert and Biquet 1989). Such films can maintain food quality and improve stability and storage life by retarding moisture exchange (gain or loss) with the surrounding environment or between two components of heterogeneous food products. Factors contributing to renewed interest in the development of edible films include consumer demand for high quality foods, environmental concerns over disposal of non-renewable food packaging materials, and opportunities for creating new market outlets for film-forming ingredients derived from agricultural commodities.

Proteins, lipids and polysaccharides can be used as edible film-forming agents (Kester and Fennema 1986, Gennadios and Weller 1991, Avena-Bustillos and Krochta 1993, McHugh et al. 1994). However, a major disadvantage of protein and polysaccharide films is their high water 
Tanada-Palmu, P. et al. Edible wheat gluten films

vapor permeability that is undesirable in edible coatings or packaging materials.

Mechanical and barrier properties of wheat gluten films have been studied (Gennadios et al. 1993a, Gontard et al. 1993, Cherian et al. 1995). In addition to the film-forming polymer, a major component of edible films is the plasticizer. Addition of a plasticizing agent is necessary to overcome film brittleness caused by intensive intermolecular forces. Plasticizers reduce these forces and increase mobility of polymer chains, thereby improving film flexibility and extensibility (Banker 1966, Guilbert and Biquet 1989). On the other hand, plasticizers generally increase gas, water vapor and solute permeability of the film (Banker 1966) and decrease the tensile strength. Properties of edible films can be strongly affected by environmental conditions such as relative humidity. Properties of wheat gluten films with different concentrations of plasticizer and at different conditions of relative humidity have not been previously reported. Our objectives were to study mechanical and barrier properties of wheat gluten films as a function of glycerol content and water activity. Applications of such films as coatings for cherry tomatoes, sharon fruits and cheese cubes also were investigated.

\section{Material and Methods}

\section{Material}

Vital wheat gluten (crude protein $78 \%$ dry basis, Cerestar, Germany) was obtained from Leipurien Tukku Oy, Finland. Beeswax was donated by Finnish Honey Producers Ltd. Ethanol (96\%, Alko Finland), glycerol (about $87 \%$, Merck, Darmstadt, Germany), ammonium hydroxide (from ammonia 25\%, Riedel-de Haën), acetic acid $(100 \%)$, calcium chloride (Merck, Darmstadt, Germany), and solid paraffin were obtained from Helsinki University's Pharmacy. Cherry tomatoes, sharon fruits and edam, em- mental and cream cheeses were obtained from a local wholesaler.

\section{Film preparation}

A film-forming solution was prepared using wheat gluten $(7.5 \mathrm{~g})$, ethanol $(45 \mathrm{ml})$, distilled water $(55 \mathrm{ml})$ and acetic acid $(50 \%)$ to adjust to $\mathrm{pH} 4$ or $6 \mathrm{~N}$ ammonium hydroxide $\left(\mathrm{NH}_{4} \mathrm{OH}\right)$ to adjust to $\mathrm{pH} 10$. Glycerol was added at concentrations of $20,25,30,35,40,45,50,55$ or $60 \%$ (w/w) of gluten. All components were mixed on a hot plate equipped with a magnetic stirrer. When acetic acid was used to adjust $\mathrm{pH}$ the solution was heated and stirred until its temperature reached $40^{\circ} \mathrm{C}$. At that temperature the stirring was continued for a further $5 \mathrm{~min}$. When ammonium hydroxide was used to adjust $\mathrm{pH}$ the solution was mixed on the magnetic stirrer until the temperature of the mixture reached $75^{\circ} \mathrm{C}$ (about $10 \mathrm{~min}$ ). The solution was then centrifuged at $7000 \mathrm{rpm}$ for $6 \mathrm{~min}$ at ambient temperature. Finally, the film-forming solution was poured and spread evenly onto a Teflon covered granite surface and dried at ambient temperature for $20 \mathrm{~h}$ (modified method from Gontard et al. 1993).

\section{Film thickness}

Film thickness was measured using a micrometer. The thickness of individual film samples was determined as an average of five measurements.

\section{Water vapor permeability}

Water vapor transmission rate of films was determined gravimetrically at $25^{\circ} \mathrm{C}$ using a modified American Society for Testing and Materials (ASTM) Standard Method E-96. The film was sealed onto a permeation cell containing calcium chloride with melted paraffin wax and placed in a conditioning chamber over saturated $\mathrm{NaCl}$ solution (75\% relative humidity, $\mathrm{RH}$ ). The wa- 
Vol. 9 (2000): 23-35.

ter vapor transferred through the film and absorbed by the desiccant was determined from the weight gain of the calcium chloride. The samples, four replicates of each film, were conditioned one day at $50 \%$ RH before measurements. Water vapor permeability (WVP) $\left(\mathrm{gmm} / \mathrm{m}^{2} \mathrm{dkPa}\right)$ was calculated as:

$\mathrm{WVP}=\mathrm{WVTR} \cdot \mathrm{L} / \Delta \mathrm{p}$,

where WVTR was measured water vapor transmission rate $\left(\mathrm{g} / \mathrm{m}^{2} \mathrm{~d}\right)$ through a film specimen; L was mean film specimen thickness $(\mathrm{mm})$; and $\Delta \mathrm{p}$ was partial water vapor pressure difference $(\mathrm{kPa})$ between the two sides of a film specimen. The effect of the air gap, as described by McHugh et al. (1993) and Gennadios et al. (1994), between the underside of the film and the surface of calcium chloride in the test cells was not taken into account in calculating water vapor transmission rates. The air gap height was approximately $0.4 \mathrm{~cm}$.

\section{Oxygen permeability}

Oxygen transmission rates were measured using a modification of ASTM Standard Method D 3985-81 with an Ox-Tran Twin apparatus (Mocon, Inc.). According to the above ASTM Standard Method specimens should be conditioned in a desiccator over calcium chloride or another suitable desiccator for a minimum of $48 \mathrm{~h}$. However, we conditioned the specimens, four replicates of each film, at 50\% RH for $24 \mathrm{~h}$, because the measurements were made using humidified oxygen and carrier gases. Test gases were humidified by drawing them through distilled water in closed bubbler tubes. This, according to the Mocon manual, provides a relative humidity of $50-75 \%$ in the test cells depending upon the rate of the flow and the level of water in the bubbler. Flow rate of the gases was adjusted to 10 $\mathrm{ml} / \mathrm{min}$ and water level in the bubblers was about $2 \mathrm{~cm}$ high. Oxygen transmission rates $\left(\mathrm{cm}^{3} / \mathrm{m}^{2} \mathrm{~d}\right)$ were determined at $25^{\circ} \mathrm{C}$. Oxygen permeability $\left(\mathrm{cm}^{3} \mu \mathrm{m} / \mathrm{m}^{2} \mathrm{dkPa}\right)$ was calculated by dividing the oxygen transmission rate by oxygen pressure and multiplying by mean film thickness. The oxygen pressure was essentially $1.013 \times 10^{5} \mathrm{~Pa}(1$ atmosphere, atm), since film samples on the measuring instrument were subjected to $100 \%$ oxygen gas on one side and a carrier gas of $98 \%$ nitrogen and $2 \%$ hydrogen on the other side.

\section{Tensile strength and percentage elongation at break}

Film tensile strength and percentage elongation at break were determined using an Instron Universal Testing Instrument (model 4465) operated according to ASTM Standard Method D 88283. Measurements were conducted at ambient temperature $\left(25^{\circ} \mathrm{C}\right)$ and relative humidity $(50 \%)$. Initial grip separation and crosshead speed were set at $100 \mathrm{~mm}$ and $100 \mathrm{~mm} / \mathrm{min}$, respectively.

Peak loads and extension at break point were recorded for tested film specimens $(150 \mathrm{~mm}$ long and $20 \mathrm{~mm}$ wide). Tensile strength of the sample was calculated by dividing peak load by cross-sectional area. Thickness of individual specimens, required to calculate cross-sectional area, was determined as an average of five micrometer readings taken on each specimen before testing. Dividing extension values by the initial grip separation $(100 \mathrm{~mm})$ and multiplying by 100 yielded percentage elongation at break. Films were conditioned for two days at each relative humidity condition before tests. Saturated salt solutions were used to obtain the following relative humidity conditions at $25^{\circ} \mathrm{C}$ : $11 \%$ with $\mathrm{LiCl}, 33 \%$ with $\mathrm{MgCl}_{2}, 52 \%$ with $\mathrm{Mg}\left(\mathrm{NO}_{3}\right)_{2}, 75 \%$ with $\mathrm{NaCl}$ and $84 \%$ with $\mathrm{KCl}$. Ten specimens of each film at each relative humidity were measured.

\section{Application of the edible film to cherry tomatoes, sharon fruits and cheese cubes}

The edible wheat gluten film prepared with ammonium hydroxide and $40 \%$ glycerol was applied to coat cherry tomatoes, sharon fruits and 


\section{Tanada-Palmu, P. et al. Edible wheat gluten films}

cheese cubes to evaluate the influence of the film on the weight loss of the product. The tests were run under controlled temperature, $10^{\circ} \mathrm{C}$ with cherry tomatoes and sharon fruits and $5^{\circ} \mathrm{C}$ with cheese cubes, for 14 days. The tomatoes used (four replicates) were about the same size and weight, and so were also the sharon fruits (two replicates). The exact degree of maturity of cherry tomatoes and sharon fruits was not known, but they were from the same lot and so at the same level of maturity. Tomatoes and sharon fruits were dipped with pliers into the film-forming solution which was at $30^{\circ} \mathrm{C}$. Sharon fruits were also coated in wheat gluten for 2 minutes, allowed to dry and then dipped into molten beeswax of $70^{\circ} \mathrm{C}$ for some seconds. During the storage test they were compared with controls without film. The cheese cubes were about the same size $(2 \times 2 \times 2 \mathrm{~cm})$ and weight; two replicates for each condition were used. They were dipped with pliers in the solution and the second layer of beeswax was also used like with sharon fruits. Some of the cubes were wrapped or sealed in pouches of wheat gluten film. Pouches were sealed by heat. Wheat gluten-coated samples were compared with samples sealed in a polyamide/low density polyethylene (PA/LDPE) or low density polyethylene (LDPE) packages.

\section{Results and discussion}

\section{Film formation}

The film-forming solution was obtained by dispersing gluten proteins in an ethanol/ammonium hydroxide or acetic acid/water solvent. During drying of the film-forming solution, ethanol and ammonia (or acetic acid) were first evaporated, leading to transition of the solution from a translucent liquid to an opaque white gel. This stage agreed with the mechanism of simple coacervation described by Kester and Fennema (1986) and was interpreted as an immobilization of polymer molecules. The gel was allowed to dry, by evaporation of the water, and a transparent film then formed.

It was noticed that wheat gluten films processed under alkaline conditions had a more yellowish color than films made with acid, in agreement with the findings of Gontard et al. (1992). However, this visual disadvantage of alkaline films is offset by their significantly higher tensile strength. The greater tensile strength of wheat gluten films cast from solutions of $\mathrm{pH} 10$ than those cast from solutions of $\mathrm{pH} 4$ (2.7 vs. $0.5 \mathrm{Mpa}$ ) was also reported by Gennadios et al. (1993a).

The film formation mechanism of wheat gluten is believed to involve intermolecular disulfide, hydrophobic and hydrogen bondings (Wall and Beckwith 1969). Sulfhydryl groups are responsible for the formation of disulfide bonds. Reduction of the disulfide bonds to sulphydryl groups and exposure of sulphydryl and hydrophobic groups (making them available for bonding) is achieved in an alkaline environment and with denaturation of protein by heating (Okamoto 1978). The dispersed gluten is then reoxidized in the air and the reformation of disulfide bonds yields the film structure.

Plasticizers are generally added to films to reduce brittleness, impart flexibility, and increase toughness, strength, tear resistance and impact resistance (Banker 1966). The mechanism by which plasticizers achieve such changes involves plasticizer-polymer interaction and reduction of cumulative intermolecular forces along polymer chains leading to "softening" of the film structure (Gennadios et al. 1993a).

Characteristics of the films produced are listed in Table 1. Films made with acetic acid needed lower amounts of plasticizer to overcome the brittleness than films made with ammonium hydroxide, but they were more fragile.

\section{Water vapor permeability}

Water vapor permeabilities of wheat gluten films are presented in Table 2. Films prepared with ammonium hydroxide had lower water vapor 
Vol. 9 (2000): 23-35.

Table 1. Characteristics of wheat gluten (WG) films plasticized with glycerol (GLY) at ambient temperature and relative humidity.

\begin{tabular}{ll}
\hline Film & Characteristics \\
\hline WG (acetic acid) 20\% GLY & too brittle and fragile \\
WG (acetic acid) 25\% GLY & flexible and transparent \\
WG (acetic acid) 30\% GLY & flexible and transparent \\
WG (acetic acid) 35\% GLY & flexible and transparent \\
WG (acetic acid) 40\% GLY & flexible and transparent \\
WG (acetic acid) 50\% GLY & too soft \\
WG $\left(\mathrm{NH}_{4} \mathrm{OH}\right) 20 \%$ GLY & too brittle and fragile \\
WG $\left(\mathrm{NH}_{4} \mathrm{OH}\right) 30 \%$ GLY & brittle and transparent \\
WG $\left(\mathrm{NH}_{4} \mathrm{OH}\right) 35 \%$ GLY & flexible and transparent \\
WG $\left(\mathrm{NH}_{4} \mathrm{OH}\right) 40 \%$ GLY & flexible and transparent \\
WG $\left(\mathrm{NH}_{4} \mathrm{OH}\right) 45 \%$ GLY & flexible and transparent \\
WG $\left(\mathrm{NH}_{4} \mathrm{OH}\right) 50 \%$ GLY & flexible and transparent \\
WG $\left(\mathrm{NH}_{4} \mathrm{OH}\right) 55 \%$ GLY & flexible, transparent, soft \\
WG $\left(\mathrm{NH}_{4} \mathrm{OH}\right) 60 \%$ GLY & flexible, transparent, soft \\
WG $\left(\mathrm{NH}_{4} \mathrm{OH}\right) 70 \%$ GLY & too soft \\
\hline
\end{tabular}

Table 2. Water vapor permeability of wheat gluten (WG) films with different levels of glycerol (GLY) at $25^{\circ} \mathrm{C}$ and $0 / 75 \%$ relative humidity.

\begin{tabular}{|c|c|c|}
\hline Film & $\begin{array}{l}\text { Water vapor permeability* } \\
\qquad\left(\mathrm{gmm} / \mathrm{m}^{2} \mathrm{dkPa}\right)\end{array}$ & $\begin{array}{c}\text { Mean thickness } \\
(\mu \mathrm{m})\end{array}$ \\
\hline $\mathrm{WG}\left(\mathrm{NH}_{4} \mathrm{OH}\right) 30 \% \mathrm{GLY}$ & $2.43 \pm 0.13^{\mathrm{a}}$ & 75 \\
\hline $\mathrm{WG}\left(\mathrm{NH}_{4} \mathrm{OH}\right) 35 \% \mathrm{GLY}$ & $3.06 \pm 0.67^{\mathrm{ab}}$ & 92 \\
\hline WG $\left(\mathrm{NH}_{4} \mathrm{OH}\right) 40 \% \mathrm{GLY}$ & $2.76 \pm 0.25^{\mathrm{a}}$ & 80 \\
\hline $\mathrm{WG}\left(\mathrm{NH}_{4} \mathrm{OH}\right) 45 \% \mathrm{GLY}$ & $3.16 \pm 0.35^{\mathrm{ab}}$ & 85 \\
\hline WG $\left(\mathrm{NH}_{4} \mathrm{OH}\right) 50 \% \mathrm{GLY}$ & $4.45 \pm 0.54^{\mathrm{bc}}$ & 102 \\
\hline $\mathrm{WG}\left(\mathrm{NH}_{4} \mathrm{OH}\right) 55 \% \mathrm{GLY}$ & $6.02 \pm 0.91^{\mathrm{cd}}$ & 97 \\
\hline $\mathrm{WG}\left(\mathrm{NH}_{4} \mathrm{OH}\right) 60 \% \mathrm{GLY}$ & $6.75 \pm 0.26^{d}$ & 85 \\
\hline WG (acetic acid) $25 \%$ GLY & $2.93 \pm 0.81^{\mathrm{ab}}$ & 71 \\
\hline WG (acetic acid) $30 \%$ GLY & $2.83 \pm 0.51^{\mathrm{a}}$ & 75 \\
\hline WG (acetic acid) 35\% GLY & $2.59 \pm 0.68^{\mathrm{ab}}$ & 66 \\
\hline WG (acetic acid) 40\% GLY & $4.10 \pm 0.77^{b}$ & 69 \\
\hline
\end{tabular}

* Mean of 4 replicates \pm standard deviation. ${ }^{a-d}$ Means with different superscripts were significantly different $(\mathrm{P}<0.01)$ according to ANOVA and Tukey's test.

permeability at the same levels of glycerol than films prepared with acetic acid. At high levels of glycerol water vapor permeability increased when the amount of glycerol was increased in accordance with Gontard et al. (1993) and Park et al. (1994a). This could be related to structural modifications of the protein network, which might become less dense, and to the hydrophilicity of glycerol, which favors adsorption and desorption of water molecules (Gontard et al. 1993).

The water vapor permeability value $(2.76 \pm$ $\left.0.25 \mathrm{gmm} / \mathrm{m}^{2} \mathrm{dkPa}\right)$ of wheat gluten $\left(\mathrm{NH}_{4} \mathrm{OH}\right) /$ $40 \%$ glycerol film, measured in our study, was 
Tanada-Palmu, P. et al. Edible wheat gluten films

Table 3. Oxygen permeability of wheat gluten (WG) films with different levels of glycerol (GLY) at $25^{\circ} \mathrm{C}$ and $50 \%$ relative humidity.

\begin{tabular}{lcc}
\hline Film & $\begin{array}{c}\text { Oxygen permeability* } \\
\left(\mathrm{cm}^{3} \mu \mathrm{m} / \mathrm{m}^{2} \mathrm{dkPa}\right)\end{array}$ & $\begin{array}{c}\text { Mean thickness } \\
(\mu \mathrm{m})\end{array}$ \\
\hline WG $\left(\mathrm{NH}_{4} \mathrm{OH}\right) 30 \%$ GLY & $2.14 \pm 0.13^{\mathrm{a}}$ & 87 \\
WG $\left(\mathrm{NH}_{4} \mathrm{OH}\right) 35 \%$ GLY & $2.94 \pm 1.01^{\mathrm{ab}}$ & 97 \\
$\mathrm{WG}\left(\mathrm{NH}_{4} \mathrm{OH}\right) 40 \%$ GLY & $3.16 \pm 0.84^{\mathrm{ab}}$ & 85 \\
$\mathrm{WG}\left(\mathrm{NH}_{4} \mathrm{OH}\right) 45 \% \mathrm{GLY}$ & $4.35 \pm 0.70^{\mathrm{bc}}$ & 95 \\
WG $\left(\mathrm{NH}_{4} \mathrm{OH}\right) 50 \%$ GLY & $5.53 \pm 0.72^{\mathrm{c}}$ & 97 \\
WG $\left(\mathrm{NH}_{4} \mathrm{OH}\right) 55 \%$ GLY & $5.87 \pm 0.80^{\mathrm{cd}}$ & 90 \\
WG $\left(\mathrm{NH}_{4} \mathrm{OH}\right) 60 \%$ GLY & $7.27 \pm 1.61^{\mathrm{d}}$ & 91 \\
\hline
\end{tabular}

* Mean of 4 replicates \pm standard deviation. ${ }^{\mathrm{a}-\mathrm{d}}$ Means with different superscripts were significantly different $(\mathrm{P}<0.01)$ according to ANOVA and Tukey's test.

lower than that $\left(4.84 \mathrm{gmm} / \mathrm{m}^{2} \mathrm{dkPa}\right.$ at $23^{\circ} \mathrm{C}$ and $11 \% \mathrm{RH})$ obtained by Gennadios et al. (1993c), for the same film. The difference can be explained by the different $\mathrm{RH}$ gradients used and the different mean thicknesses of our film and the one by Gennadios et al. (80 and $101 \mu \mathrm{m}$, respectively). Hydrophilic films have been shown to exhibit positive slope relationships between thickness and water vapor permeability (McHugh et al. 1993, Cuq et al. 1996). Therefore, WVP values of the various films in Table 2 should be compared with caution, because there were substantial thickness differences among the films.

\section{Oxygen permeability}

Oxygen permeability of wheat gluten films made with ammonium hydroxide are shown in Table 3. Oxygen permeability could not be measured for films made with acetic acid because they were too fragile and cracked in the test cell.

Wheat gluten film made with $40 \%$ glycerol had an oxygen permeability almost identical to the value obtained by Gennadios et al. (1993c) for a similar film $\left(3.82 \mathrm{~cm}^{3} \mu \mathrm{m} / \mathrm{m}^{2} \mathrm{dkPa}\right.$, at $23^{\circ} \mathrm{C}$ and $0 \% \mathrm{RH}$ ). Oxygen permeability of all the wheat gluten films was low but increased with increasing glycerol concentration. Water increases the free volume of the polymer, thereby increasing polymer mobility and permeability. Polyol plasticizers, such as glycerol, are hypothesized to act in the same manner (McHugh and Krochta 1994).

The low oxygen permeability of wheat gluten films may be due to their polar nature and linear structure, leading to high cohesive energy density and low free volume. In our study, wheat gluten films had oxygen permeabilities which were of the same magnitude as those of PVDC (polyvinylidene chloride)-based films (0.4-5.1 $\mathrm{cm}^{3} \mu \mathrm{m} / \mathrm{m}^{2} \mathrm{dkPa}$, at $23^{\circ} \mathrm{C}$ and $50 \% \mathrm{RH}$ ), as reported by Salame (1986).

\section{Tensile strength and percentage elongation at break}

Unplasticized gluten film could not be measured as it was too brittle. Wheat gluten films made with acetic acid were also too fragile. The effect of glycerol on the mechanical properties of films is illustrated in Figs. 1 and 2. Tensile strength decreased and percentage elongation at break increased with an increase in glycerol content, in accordance with Park et al. (1993). Similar 
Fig. 1. Effect of water activity on tensile strength of wheat gluten (WG) films plasticized with different amounts of glycerol (GLY).
Vol. 9 (2000): 23-35.
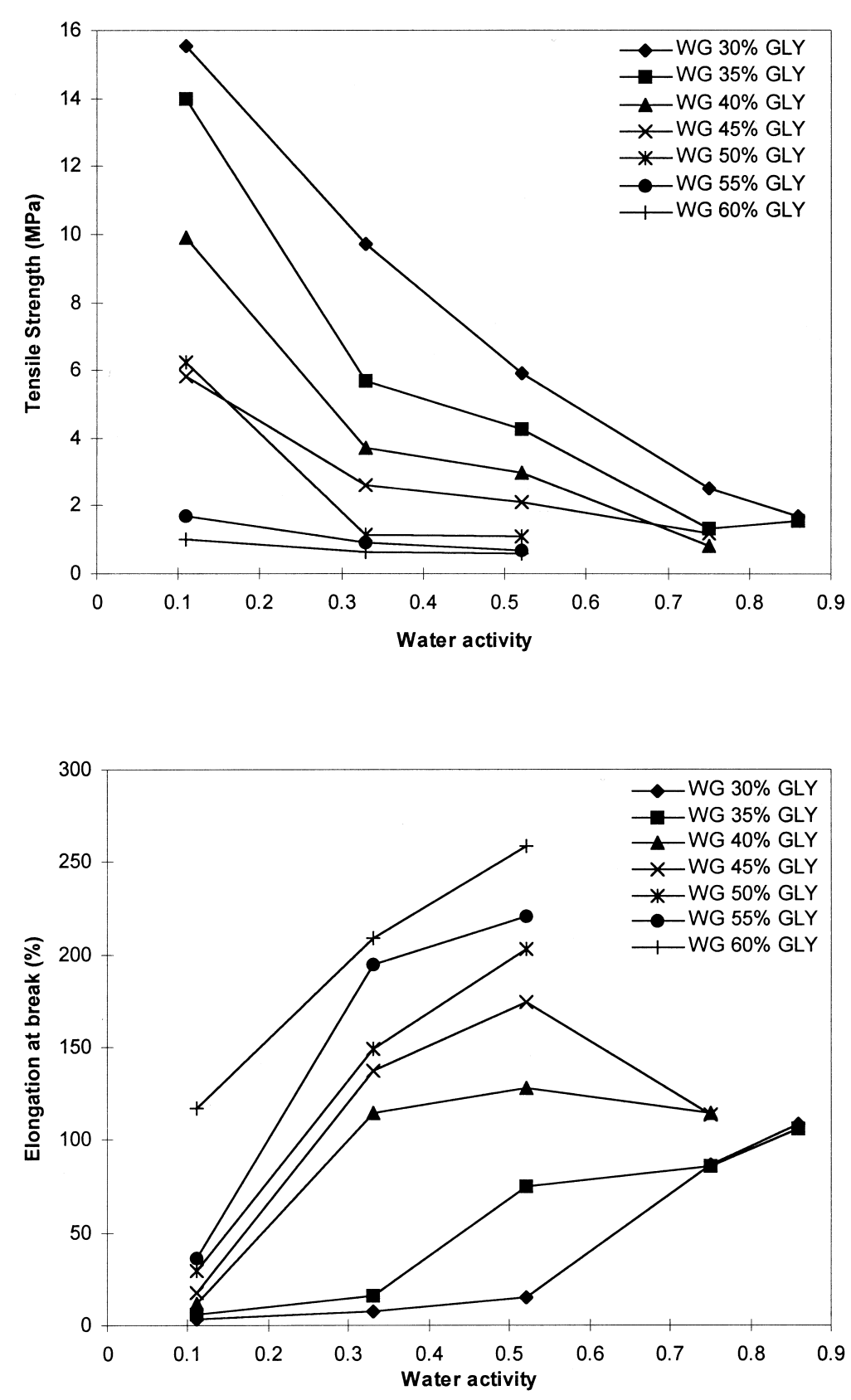

Fig. 2. Effect of water activity on percentage elongation at break of wheat gluten (WG) films plasticized with different amounts of glycerol (GLY). decreased tensile strength and increased percentage elongation at break with increasing amounts of plasticizer have been reported for other protein films, such as glycerol-plasticized whey pro- tein isolate (McHugh and Krochta 1994) and egg albumen films (Gennadios et al. 1996).

The plasticization effect of glycerol can be explained by the great number of hydrogen bonds 


\section{AGRICULTURAL AND FOOD SCIENCE IN FINLAND}

\section{Tanada-Palmu, P. et al. Edible wheat gluten films}

between protein chains (Gontard et al. 1993), resulting from the high glutamine content (about $45 \%$ ) of wheat gluten proteins. Glycerol as a relatively small hydrophilic molecule could be easily inserted between protein chains and form hydrogen bonds with amide groups of gluten proteins. When glycerol was added to the gluten network, direct interactions between protein chains were reduced and the distance between the chains was increased. So, under stress, movements of protein chains were facilitated in gluten films plasticized with glycerol.

Tensile strength values of ammonium-treated gluten films plasticized with $35 \%$ or $40 \%$ glycerol at $\mathrm{a}_{\mathrm{w}}$ of 0.52 were similar to reported values (3.9 and 2.6 MPa, respectively) by Gennadios et al. (1993b, c).

The tensile strength and the percentage elongation at break are strongly affected by water activity. We measured the tensile strength and the percentage elongation at break of wheat gluten films that had been conditioned at different RHs for 2 days before testing. This approach has not been earlier reported by wheat gluten film researchers. The effect of $a_{w}$ on the tensile strength and percentage elongation at break is shown in Figs. 1 and 2.

The tensile strength decreased and the percentage elongation at break increased with increasing $\mathrm{a}_{\mathrm{w}}$. At high $\mathrm{a}_{\mathrm{w}}$, films were more flexible and extensible, but could withstand less tensile stress. Decrease in tensile strength was greater at drier conditions $\left(\mathrm{a}_{\mathrm{w}}\right.$ of 0.11 or 0.33$)$ as a function of glycerol content and also greater with smaller amounts of glycerol (30 or $35 \%$ ) as a function of $a_{w}$. The percentage elongation at break of films increased up to $\mathrm{a}_{\mathrm{w}}$ of 0.52 , as a function of glycerol content; the largest increase as a function of water activity, was observed with films containing 50 and 55\% glycerol. The percentage elongation at break at higher relative humidities (above 52\%) decreased for films containing 40 and $45 \%$ glycerol but increased for films containing 30 and $35 \%$ glycerol. The tensile strength and the percentage elongation at break for wheat gluten films with high amounts of glycerol (above $45 \%$ ) could not be measured at $\mathrm{a}_{\mathrm{w}}$ above 0.52 because films were too soft, like chewing gum.

\section{Application of wheat gluten film to cherry tomatoes, sharon fruits and cheese cubes}

Moisture loss due to transpiration during storage was observed for cherry tomatoes, sharon fruits and cheese cubes. Edible wheat gluten film coatings were applied in order to reduce weight loss during storage. Comparisons of moisture loss between controls and coated products during 2 weeks of storage, in terms of $\%$ weight loss, are illustrated in Figs. 3, 4, 5, 6 and 7.

Tomatoes dipped in acetic acid-treated wheat gluten film solution were glossy, whereas those dipped in ammonium hydroxide-treated solution were opaque. Uncoated tomatoes shrivelled severely and lost weight faster than the coated samples. Tomatoes dipped in wheat gluten solutions had a better texture (less soft and soggy) than those without film. Those dipped in wheat gluten (acetic acid) solution had the best appearance; they appeared to be intact and firm, however they were somewhat softened inside. They also had not lost so much water (Fig. 3).

Sharon fruits with bilayer film (wheat gluten $\left(\mathrm{NH}_{4} \mathrm{OH}\right) 40 \%$ glycerol and beeswax) were opaque and white because of the beeswax. Fruits without film lost weight faster and softened. Fruits with film were intact and firm. Fruits treated with beeswax also had the lowest weight loss (Fig. 4).

The wheat gluten film reduced moisture loss from sharon fruits and cherry tomatoes. Park et al. (1994b) reported that a corn zein film behaved similarly with tomatoes. Lerdthanangkul and Krochta (1996) observed that a mineral-oil-based coating reduced moisture loss from green bell peppers. Starch-based films reduced moisture loss from strawberries (García et al. 1998).

All cheese cubes with wheat gluten $\left(\mathrm{NH}_{4} \mathrm{OH}\right)$ $40 \%$ glycerol film (dipped, sealed in pouches, 
Vol. 9 (2000): 23-35.

Fig. 3. Weight changes of wheat gluten (WG) coated and uncoated cherry tomatoes during storage.

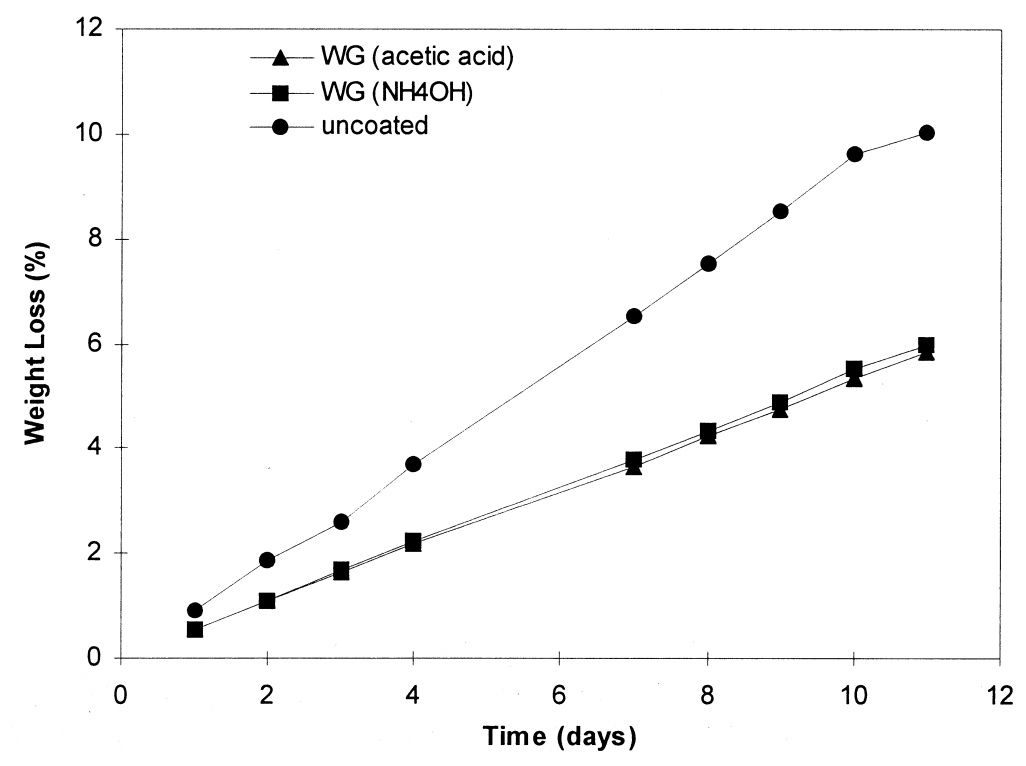

Fig. 4. Weight changes of wheat gluten (WG) coated and uncoated sharon fruits during storage.

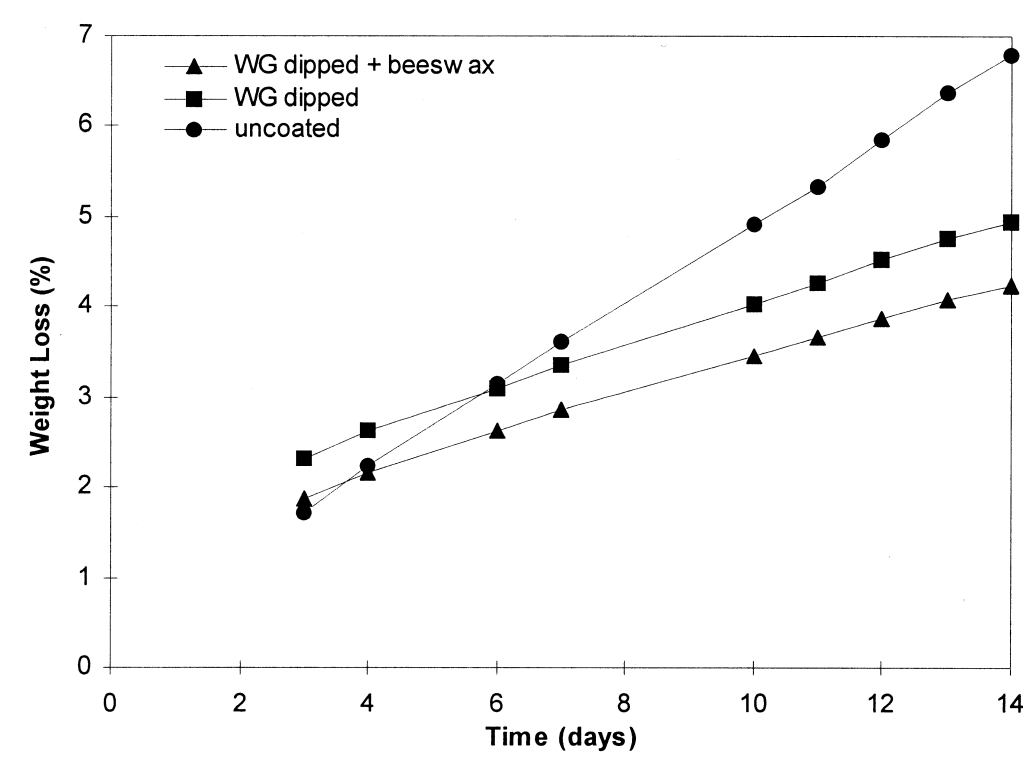

or wrapped) had higher weight losses (Figs. 5, 6 and 7) than those packed in laminated PA/LDPE or LDPE film. However, cheese cubes with a bilayer coat (dipped in wheat gluten film-form- ing solution and with a second layer of beeswax) had relatively low weight loss. This was more evident with edam cheese cubes. Bilayer coating of wheat gluten and beeswax reduced mois- 


\section{AGRICULTURAL AND FOOD SCIENCE IN FINLAND}

Tanada-Palmu, P. et al. Edible wheat gluten films

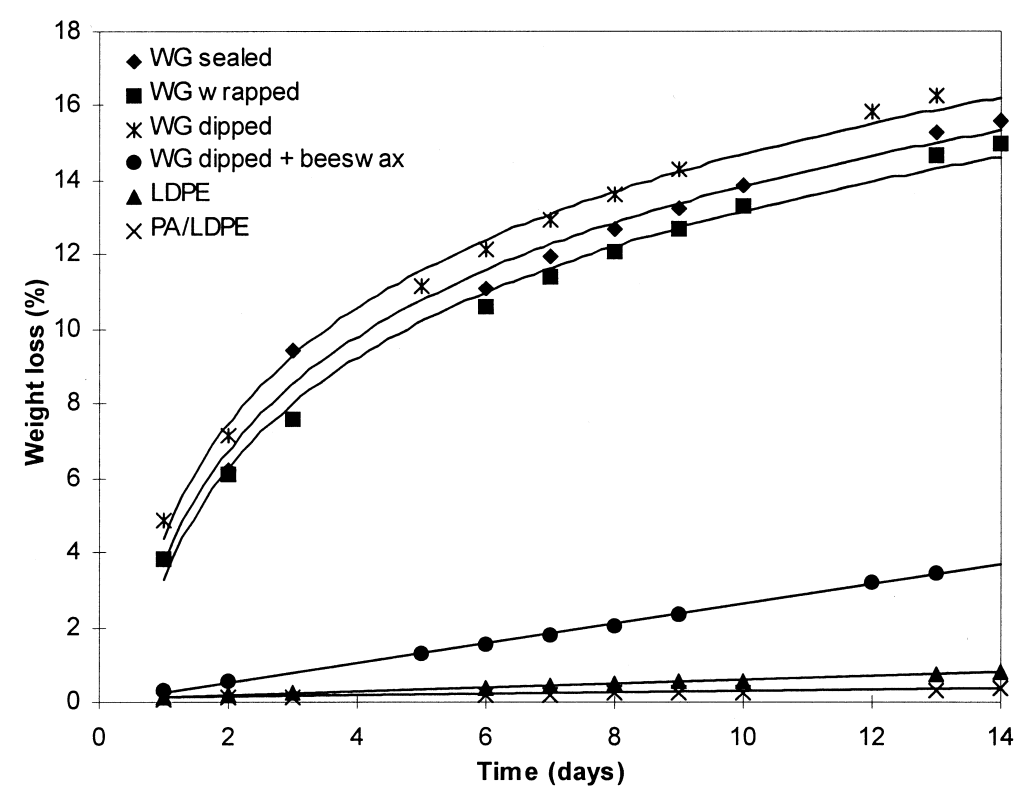

Fig. 5. Weight changes of edible wheat gluten (WG) film-coated, low density polyethylene (LDPE)packed and polyamide/low density polyethylene (PA/LDPE)packed cheese cubes during storage.

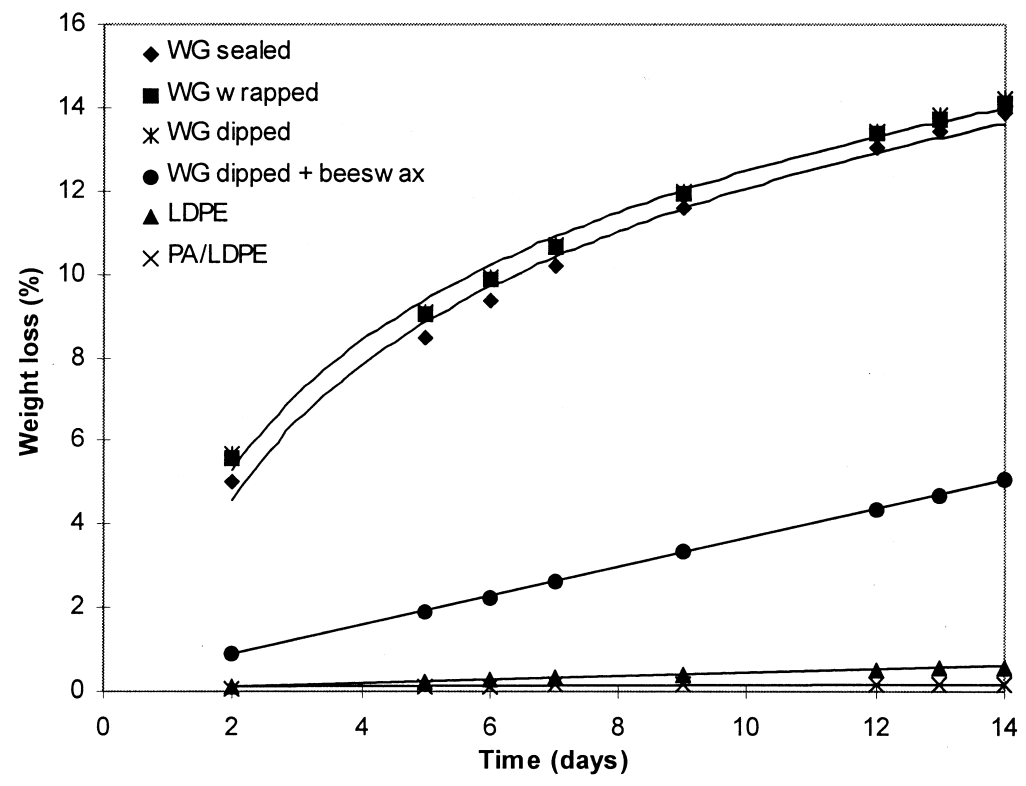

Fig. 6. Weight changes of edible wheat gluten (WG) film-coated, low density polyethylene (LDPE)packed and polyamide/low density polyethylene (PA/LDPE)packed emmental cheese cubes during storage. ture loss from cheese cubes throughout storage but not the wheat gluten film without beeswax. The results showed the necessity of a second lay- er of lipid to improve water vapor barrier ability of wheat gluten films to control the moisture loss from coated products. 
Fig 7. Weight changes of edible wheat gluten (WG) film-coated, polyamide/low density polyethylene (PA/LDPE)-packed and low density polyethylene (LDPE)packed edam cheese cubes during storage.
Vol. 9 (2000): 23-35.

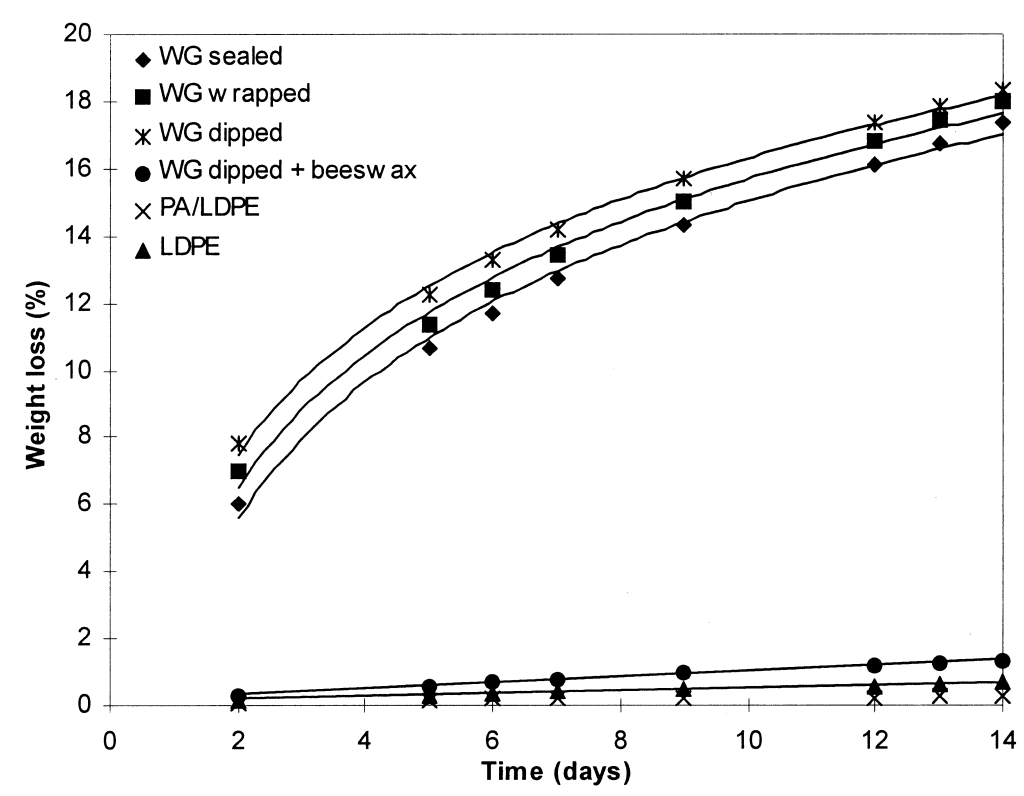

\section{Conclusions}

Wheat gluten has potential for use in proteinbased edible films and coatings. Films prepared from wheat gluten with ammonium hydroxide had low oxygen permeability and high tensile strength at low $\mathrm{a}_{\mathrm{w}}$. Amount of plasticizers, water and glycerol, influenced film properties. Glutenbased films showed promise as protective coat- ing materials for perishable foods such as cherry tomatoes and sharon fruits. However, an additional lipid layer is necessary to reduce water vapor permeability. Future research should explore possibilities of improving wheat gluten film properties by promoting crosslinking through enzymatic and chemical protein treatments. Development of edible films from wheat gluten will enhance its value and may provide new markets for wheat gluten.

\section{References}

ASTM 1989. Annual Book of ASTM Standards. American Society for Testing and Materials. Philadelphia, PA.

Avena-Bustillos, R.J. \& Krochta, J.M. 1993. Water vapor permeability of caseinate-based edible films as affected by $\mathrm{pH}$, calcium crosslinking and lipid content. Journal of Food Science 58: 904-907.

Banker, G.S. 1966. Film coating theory and practice. Journal of Pharmaceutical Sciences 55: 81-89.

Cherian, G., Gennadios, A., Weller, C.L. \& Chinachoti, P. 1995. Thermomechanical behavior of wheat gluten films: effect of sucrose, glycerin, and sorbitol. Cereal Chemistry 72: 1-6.

Cuq, B., Gontard, N., Cuq, J.L. \& Guilbert, S. 1996. Functional properties of myofibrillar protein-based biopackaging as affected by film thickness. Journal of Food Science 61: 580-584.

García, M.A., Martino, M.N. \& Zaritzky, N.E. 1998. Starchbased coatings: effect on refrigerated strawberry (Fragaria ananassa) quality. Journal of the Science of Food and Agriculture 76: 411-420.

Gennadios, A., Brandenburg, A.H., Weller, C.L. \& Testin, 
Tanada-Palmu, P. et al. Edible wheat gluten films

R.F. 1993a. Effect of $\mathrm{pH}$ on properties of wheat gluten and soy protein isolate films. Journal of Agricultural and Food Chemistry 41: 1835-1839.

-, Park, H.J. \& Weller, C.L. 1993b. Relative humidity and temperature effects on tensile strength of edible protein and cellulose ether films. Transactions of ASAE 36: 1867-1872.

- \& Weller, C.L. 1991. Edible films and coatings from soy milk and soy protein. Cereal Foods World 36: 1004-1009.

-, Weller, C.L. \& Gooding, C.H. 1994. Measurement errors in water vapor permeability of highly permeable, hydrophilic edible films. Journal of Food Engineering. 21: 395-409.

-, Weller, C.L., Hanna, M.A. \& Froning, G.W. 1996. Mechanical and barrier properties of egg albumen films. Journal of Food Science 61: 585-589.

-, Weller, C.L. \& Testin, R.F. 1993c. Property modification of edible wheat gluten-based films. Transactions of ASAE 36: 465-470.

Gontard, N., Guilbert, S. \& Cuq, J.L. 1992. Edible wheat gluten films: influence of the main process variables on film properties using response surface methodology. Journal of Food Science 57: 190-195, 199.

-, Guilbert, S. \& Cuq, J.L. 1993. Water and glycerol as plasticizers affect mechanical and water vapor barrier properties of an edible wheat gluten film. Journal of Food Science 58: 206-211.

Guilbert, S. 1986. Technology and application of edible protective films. In: Mathlouthi, M. (ed.). Food Packaging and Preservation. Theory and Practice. Elsevier Applied Science Publishing Co., London, England. p. 371.

- \& Biquet, B. 1989. Les films et enrobage comestibles. Ch. 22. In: Bureau, G. \& Multon, J.L. (eds.). L'emballage des denrées alimentaires de grande consommation, Technique et Documentation, Lavoisier, Apria, Paris, France. p. 320.

Kester, J.J. \& Fennema, O. 1986. Edible films and coatings: a review. Food Technology 40, 12: 47-59.

Lerdthanangkul, S. \& Krochta, J.M. 1996. Edible coating effects on postharvest quality of green bell peppers.
Journal of Food Science 61: 176-179.

McHugh, T.H., Aujard, J.F. \& Krochta, J.M. 1994. Plasticized whey protein edible films: water vapor permeability properties. Journal of Food Science 59: 416419, 423.

-, Avena-Bustillos, R. \& Krochta, J.M. 1993. Hydrophilic edible films: modified procedure for water vapor permeability and explanation of thickness effects. Journal of Food Science 58: 899-903.

- \& Krochta, J.M. 1994. Sorbitol- vs glycerol-plasticized whey protein edible films: Integrated oxygen permeability and tensile property evaluation. Journal of Agricultural and Food Chemistry 42: 841-845.

Miller, K.S. \& Krochta, J.M. 1997. Oxygen and aroma barrier properties of edible films: a review. Trends in Food Science \& Technology 8: 228-237.

Okamoto, S. 1978. Factors affecting protein film formation. Cereal Foods World 23: 256-262.

Park, H.J., Bunn, J.M., Weller, C.L., Vergano, P.J. \& Testin, R.F. 1994a. Water vapor permeability and mechanical properties of grain protein-based films as affected by mixtures of polyethylene glycol and glycerin plasticizers. Transactions of ASAE 37: 12811285.

-, Chinnan, M.S. \& Shewfelt, R.L. 1994b. Edible coating effects on storage life and quality of tomatoes. Journal of Food Science 59: 568-570.

-, Weller, C.L., Vergano, P.J. \& Testin, R.F. 1993. Permeability and mechanical properties of cellulosebased edible films. Journal of Food Science 58: $1361-1364$

Salame, M. 1986. Barrier polymers. In: Bakker, M. (ed.). The Wiley Encyclopedia of Packaging Technology. John Wiley \& Sons, New York. p. 48-54.

Slade, L. \& Levine, H. 1991. Beyond water activity: recent advances based on an alternative approach to the assessment of food quality and safety. Critical Reviews in Food Science and Nutrition 30: 115-360.

Wall, J.S. \& Beckwith, A.C. 1969. Relationship between structure and rheological properties of gluten proteins. Cereal Science Today 14, 1: 16-18, 20-21. 
Vol. 9 (2000): 23-35.

\section{SELOSTUS}

\section{Syötävien gluteenikalvojen valmistus, ominaisuudet ja eräät käyttösovellukset}

Patricia S. Tanada-Palmu, Harry Helén ja Lea Hyvönen

Helsingin yliopisto

Elintarvikkeiden pakkaamiseen soveltuvien syötävien kalvojen kehittäminen on ollut viime vuosina voimakkaan mielenkiinnon kohteena. Tässä tutkimuksessa valmistettiin kalvoja vehnägluteenista käyttäen pehmittimenä eri määriä glyserolia. Kalvojen läpäisevyysominaisuuksia tutkittiin määrittämällä niiden vesihöyryn- ja hapenläpäisevyydet. Glyserolipitoisuutta lisättäessä kalvojen kaasunsuojaominaisuudet heikkenivät. Kalvojen lujuusominaisuuksia tutkittiin mittaamalla niiden vetolujuudet ja murtovenymät erilaisissa vedenaktiivisuuksissa. Glyserolipitoisuuden kasvaessa kalvojen vetolujuus heikkeni ja prosentuaalinen murtovenymä suureni. Tämä vaikutus oli selvempi pienissä vedenaktiivisuuksissa. Kalvojen soveltuvuutta elintarvikepakkaamiseen tutkittiin päällystämällä niillä kirsikkatomaatteja, sharon-hedelmiä ja kolmenlaisia juustopaloja. Gluteenipäällysteet hidastivat selvästi kirsikkatomaattien ja sharon-hedelmien painon alenemista kahden viikon säilytyksen aikana verrattuna päällystämättömiin näytteisiin. Juustopalojen yhteydessä havaittiin mehiläisvahan käyttämisen toisena kalvokerroksena gluteenin päällä pienentävän merkittävästi syötävällä kalvolla päällystetyn juuston painotappiota kahden viikon säilytyksen aikana. 
